Article

\title{
Kansuinine A Ameliorates Atherosclerosis and Human Aortic Endothelial Cell Apoptosis by Inhibiting Reactive Oxygen Species Production and Suppressing IKK $\beta / \mathrm{I} \kappa \mathrm{B} \alpha / \mathrm{NF}-\kappa \mathrm{B}$ Signaling
}

\author{
Chen-Sheng Chen ${ }^{1,+} \mathbb{D}$, Bo-Yi Pan ${ }^{2,+}$, Ping-Hsuan Tsai ${ }^{2} \mathbb{D}$, Fang-Yu Chen ${ }^{2}$, Wen-Chin Yang ${ }^{3}(\mathbb{D}$ \\ and Ming-Yi Shen $2,4,5, *$ (D)
}

Citation: Chen, C.-S.; Pan, B.-Y.; Tsai, P.-H.; Chen, F.-Y.; Yang, W.-C.; Shen, M.-Y. Kansuinine A Ameliorates Atherosclerosis and Human Aortic Endothelial Cell Apoptosis by Inhibiting Reactive Oxygen Species Production and Suppressing $\mathrm{IKK} \beta / \mathrm{I} \kappa \mathrm{B} \alpha / \mathrm{NF}-\kappa \mathrm{B}$ Signaling. Int. J. Mol. Sci. 2021, 22, 10309. https:// doi.org/10.3390/ijms221910309

Academic Editors: Suowen Xu, Peter J. Little and Jianping Weng

Received: 13 September 2021 Accepted: 22 September 2021 Published: 24 September 2021

Publisher's Note: MDPI stays neutral with regard to jurisdictional claims in published maps and institutional affiliations.

Copyright: (c) 2021 by the authors. Licensee MDPI, Basel, Switzerland. This article is an open access article distributed under the terms and conditions of the Creative Commons Attribution (CC BY) license (https:// creativecommons.org/licenses/by/ $4.0 /)$.
1 The Ph.D. Program for Cancer Biology and Drug Discovery, China Medical University and Academia Sinica, 91, Hsueh-Shih Rd., Taichung 40402, Taiwan; U105071204@cmu.edu.tw

2 Graduate Institute of Biomedical Sciences, China Medical University, 91, Hsueh-Shih Rd., Taichung 40402, Taiwan; U106010831@cmu.edu.tw (B.-Y.P.); U105010312@cmu.edu.tw (P.-H.T.); fyc0321@gmail.com (F.-Y.C.)

3 Agricultural Biotechnology Research Center, Academia Sinica, 128, Sec. 2, Academia Rd., Nankang, Taipei 11529, Taiwan; wcyang@gate.sinica.edu.tw

4 Department of Medical Research, China Medical University Hospital, 91, Hsueh-Shih Rd., Taichung 40402, Taiwan

5 Department of Nursing, Asia University, 500, Lioufeng Rd., Wufeng, Taichung 41354, Taiwan

* Correspondence: shenmy1124@gmail.com; Tel.: +886-4-2205-3366

+ These authors have contributed equally to this work and share first authorship.

Abstract: Reactive oxygen species (ROS)-induced vascular endothelial cell apoptosis is strongly associated with atherosclerosis progression. Herein, we aimed to examine whether Kansuinine A (KA), extracted from Euphorbia kansui L., prevents atherosclerosis development in a mouse model and inhibits cell apoptosis through oxidative stress reduction. Atherosclerosis development was analyzed in apolipoprotein E-deficient $\left(\mathrm{ApoE}^{-/-}\right)$mice fed a high-fat diet (HFD) using Oil Red O staining and H\&E staining. Human aortic endothelial cells (HAECs) were treated with KA, followed by hydrogen peroxide $\left(\mathrm{H}_{2} \mathrm{O}_{2}\right)$, to investigate the KA-mediated inhibition of ROS-induced oxidative stress and cell apoptosis. Oil Red $\mathrm{O}$ staining and $\mathrm{H} \& \mathrm{E}$ staining showed that atherosclerotic lesion size was significantly smaller in the aortic arch of $A p o E^{-/-}$mice in the HFD+KA group than that in the aortic arch of those in the HFD group. Further, $\mathrm{KA}(0.1-1.0 \mu \mathrm{M})$ blocked the $\mathrm{H}_{2} \mathrm{O}_{2}$-induced death of HAECs and ROS generation. The $\mathrm{H}_{2} \mathrm{O}_{2}$-mediated upregulation of phosphorylated IKK $\beta$, phosphorylated $\mathrm{I} \kappa \mathrm{B} \alpha$, and phosphorylated NF- $\mathrm{B}$ was suppressed by KA. KA also reduced the Bax/Bcl-2 ratio and cleaved caspase-3 expression, preventing $\mathrm{H}_{2} \mathrm{O}_{2}$-induced vascular endothelial cell apoptosis. Our results indicate that KA may protect against ROS-induced endothelial cell apoptosis and has considerable clinical potential in the prevention of atherosclerosis and cardiovascular diseases.

Keywords: Kansuinine A; anti-atherogenic drug; atherosclerosis; reactive oxygen species; human aortic endothelial cells

\section{Introduction}

Cardiovascular diseases (CVDs), such as atherosclerosis-mediated myocardial infarction or stroke, are the leading cause of morbidity and mortality. These diseases are responsible for an estimated 17.9 million deaths each year, accounting for $31 \%$ of all deaths worldwide and placing a huge economic burden on health care systems globally [1,2]. The progression of CVDs is influenced by several factors, such as aging, hypertension, and atherosclerosis [3]. These factors are associated with a long-term increase in oxidative stress, which causes vascular endothelial damage, due to the overproduction of reactive oxygen species (ROS) [4]. Hydrogen peroxide $\left(\mathrm{H}_{2} \mathrm{O}_{2}\right)$ is an $\mathrm{ROS}$ that induces ischemia-reperfusion 
injury in animal models, and in vitro studies on CVDs have shown that $\mathrm{H}_{2} \mathrm{O}_{2}$-induced oxidative stress in endothelial cells causes apoptosis [5]. Large amounts of ROS lead to an increase in free radicals and lipid peroxides, which play a role in the pathogenesis of degenerative diseases, such as atherosclerosis [6]. Thus, interventions that inhibit ROS-induced endothelial cell damage would prevent atherosclerosis and provide insights to develop a platform for screening anti-atherogenic drugs to prevent the development of CVDs.

Medicinal herbs have been widely used to treat various diseases in several countries [7-10]. To reduce the severity of various diseases, chemicals from plants can be used as complementary and alternative medicinal agents, providing antioxidative, antiinflammatory, and cell-/tissue-protective effects [11,12], especially for the treatment of CVDs $[13,14]$. Evidence strongly indicates that several natural products or herbs have potent anti-inflammatory and antioxidant properties [12,14,15]. Kansuinine A (KA; Figure 1A) is extracted from Euphorbia kansui L., a well-known medicinal plant in China. Euphorbia kansui extract acts on the intestinal smooth muscles to stimulate the intestines, resulting in the propulsion of feces [16]. Furthermore, 3-O-(2,3-dimethylbutanoyl)-13-O-decanoylingenol, purified from E. kansui extract, displays therapeutic potential against allergic diseases, and the underlying mechanism involves the inhibition of intracellular signaling pathways to activate and release chemical mediators from mast cells [17]. Mice treated with stir-fried Radix Kansui and vinegar showed a significant increase in Bcl-2 expression and decrease in caspase-3, NF- $\mathrm{kB}$, and ICAM-1 expression [18]. It is worth noting that KA may reduce inflammation, regulate anti-apoptotic and pro-apoptotic mediators in the mitochondrial pathway [18], and improve the inflammatory response [19].

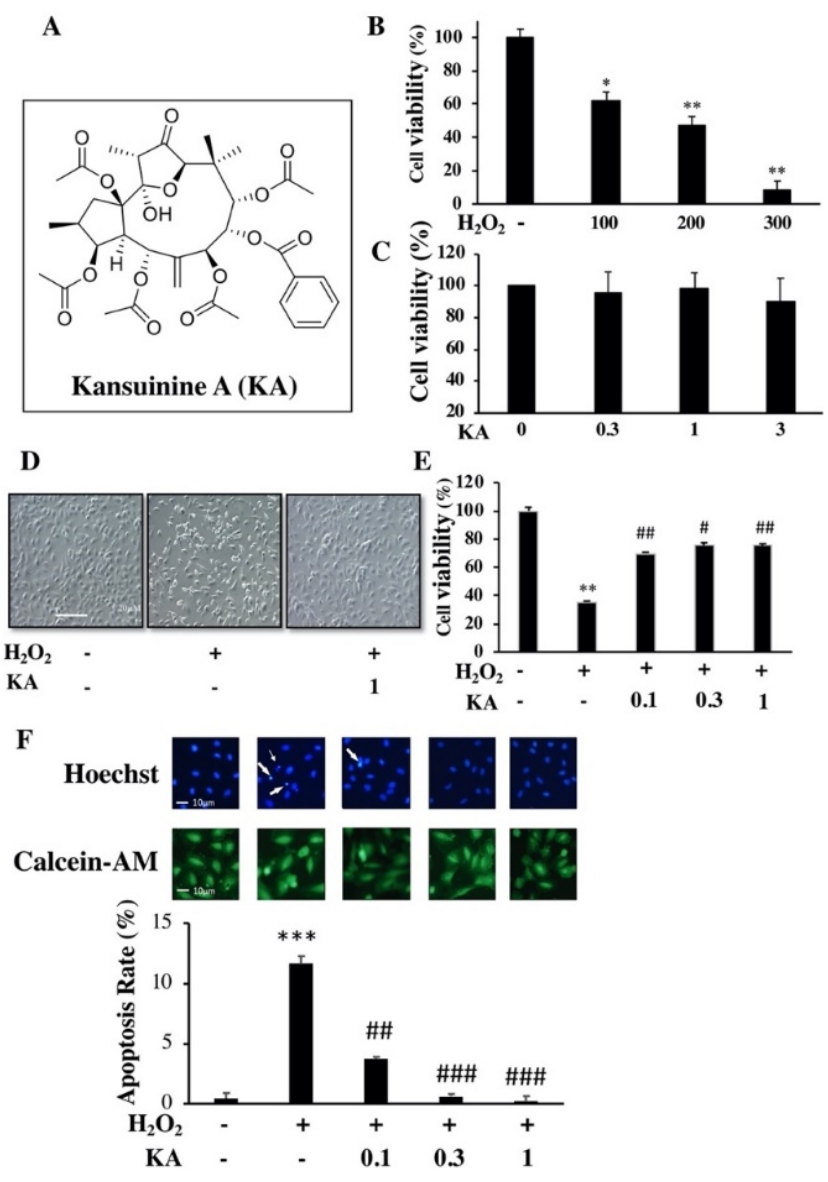

Figure 1. Effects of Kansuinine A (KA) on cell viability and apoptosis. (A) The structure of KA. (B) Effect of hydrogen peroxide $\left(\mathrm{H}_{2} \mathrm{O}_{2}\right)$ on the viability of human aortic endothelial cells (HAECs). 
HAECs were treated with various concentrations of $\mathrm{H}_{2} \mathrm{O}_{2}$ for $24 \mathrm{~h}$. (C) Nontoxicity of KA. HAECs were treated with various KA concentrations for $24 \mathrm{~h}$. (D) Effect of KA on $\mathrm{H}_{2} \mathrm{O}_{2}$-treated HAECs. Representative image of the effect of KA $(1 \mu \mathrm{M})$ on the morphology of $\mathrm{H}_{2} \mathrm{O}_{2}$-treated HAECs obtained using an inverted phase-contrast microscope. (E) Effect of KA on HAECs damaged by $\mathrm{H}_{2} \mathrm{O}_{2}$. (F) Representative images and quantification of Hoechst 33342 (nuclear morphology) and calcein-AM (membrane integrity) staining. HAECs were pre-treated with various KA concentrations $(0.1,0.3$, and $1.0 \mu \mathrm{M})$ for $1 \mathrm{~h}$, and then with $\mathrm{H}_{2} \mathrm{O}_{2}(200 \mu \mathrm{M})$ for $24 \mathrm{~h}$. Thereafter, cell viability was determined using the MTT assay. Data are presented as the mean \pm standard deviation $(n=3)$. $p$ Values were determined using the Student's $t$-test. ${ }^{*} p<0.05,{ }^{* *} p<0.01,{ }^{* * *} p<0.001$ vs. control group; $\#<0.05$, \#\# $p<0.01$, \#\#\# $p<0.001$ vs. $\mathrm{H}_{2} \mathrm{O}_{2}$ group.

This study aimed to investigate the effects of $\mathrm{KA}$ on $\mathrm{H}_{2} \mathrm{O}_{2}$-induced endothelial cell injury and atherosclerosis development in a mouse model. Additionally, we systematically explored the mechanisms underlying these effects.

\section{Results}

\subsection{Effects of $\mathrm{KA}$ on the Viability of $\mathrm{H}_{2} \mathrm{O}_{2}$-Injured Human Aortic Endothelial Cells (HAECs)}

To assess whether KA protects endothelial cells against ROS-induced injury, we first used the MTT assay to examine the viability of $\mathrm{H}_{2} \mathrm{O}_{2}$-injured HAECs. The data showed that $\mathrm{H}_{2} \mathrm{O}_{2}$ reduced HAEC activity in a concentration-dependent manner, and the half maximal inhibitory concentration of $\mathrm{H}_{2} \mathrm{O}_{2}$ was $200 \mu \mathrm{M}$ (Figure 1B). Additionally, KA at concentrations up to $3 \mu \mathrm{M}$ did not exert any significant cytotoxic effect $(p=0.62, \mathrm{n}=3$; Figure 1C); therefore, all subsequent experiments were performed at a dose not higher than $3 \mu \mathrm{M}$. The number of cells in the $\mathrm{H}_{2} \mathrm{O}_{2}(200 \mu \mathrm{M})$ group was significantly reduced compared to that in the control group, and the number of cells in the $\mathrm{H}_{2} \mathrm{O}_{2}(200 \mu \mathrm{M})$ group that received the KA $(1 \mu \mathrm{M})$ treatment did not change significantly (Figure 1D). Moreover, the cells were pre-incubated with various KA concentrations $(0.1-1.0 \mu \mathrm{M})$ for $60 \mathrm{~min}$ and then challenged with $\mathrm{H}_{2} \mathrm{O}_{2}(200 \mu \mathrm{M})$ for $24 \mathrm{~h}$. The results showed that $\mathrm{H}_{2} \mathrm{O}_{2}$ significantly reduced the viability of these HAECs $(p<0.01, \mathrm{n}=3)$. Conversely, KA pre-incubation (0.1-1.0 $\mu \mathrm{M})$ protected cells from $\mathrm{H}_{2} \mathrm{O}_{2}$-induced cell damage $(p<0.01$ at 0.1 and $1.0 \mu \mathrm{M}$ and $p<0.05$ at $0.3 \mu \mathrm{M} ; \mathrm{n}=3$; Figure $1 \mathrm{E}$ ). To further evaluate whether KA can protect HAECs against $\mathrm{H}_{2} \mathrm{O}_{2}$-induced cell damage, HAECs were treated with $\mathrm{H}_{2} \mathrm{O}_{2}$, followed by the addition of $\mathrm{KA}$ at various concentrations. After $\mathrm{H}_{2} \mathrm{O}_{2}$ treatment, Hoechst 33342 staining revealed chromosomal breakage fragments, while calcein-AM staining revealed ruptured cell membranes. The results of fluorescence microscopy showed that $\mathrm{H}_{2} \mathrm{O}_{2}$ induced cell apoptosis (Figure 1F; $p<0.001$ compared with controls). However, the addition of KA reduced the number of chromosomal breakage fragments and maintained cell membrane integrity $\left(p<0.001\right.$ at 0.3 and $1.0 \mu \mathrm{M}$ compared with $\mathrm{H}_{2} \mathrm{O}_{2}$ alone; $\mathrm{n}=3$; Figure $\left.1 \mathrm{~F}\right)$. These results indicate that $\mathrm{KA}$ may protect cells from $\mathrm{H}_{2} \mathrm{O}_{2}$-induced damage.

\subsection{Effect of $\mathrm{KA}$ on Intracellular ROS Generation in $\mathrm{H}_{2} \mathrm{O}_{2}$-Treated $\mathrm{HAECS}$}

To elucidate whether the protective effect of KA is mediated by a reduction in intracellular oxidative stress, intracellular ROS generation was determined using $2^{\prime}, 7^{\prime}$ Dichlorofluorescein diacetate (DCFH-DA). $\mathrm{H}_{2} \mathrm{O}_{2}$ significantly increased the level of ROS, reaching the highest level after $2 \mathrm{~h}$, compared with that in the control group, and KA $(0.1-1.0 \mu \mathrm{M})$ inhibited this effect in a concentration-dependent manner (Figure 2A). This finding suggests that KA may arrest $\mathrm{H}_{2} \mathrm{O}_{2}$-induced intracellular ROS generation.

\subsection{Effect of KA on the Protein Expression Levels of Bax, Bcl-2, and Cleaved Caspase-3 (CC3) in} $\mathrm{H}_{2} \mathrm{O}_{2}$-Treated HAECs

Expression levels of Bax (pro-apoptotic factor), Bcl-2 (anti-apoptotic factor), and cleaved caspase-3 (CC3, apoptosis marker) in $\mathrm{H}_{2} \mathrm{O}_{2}$-treated HAECs were evaluated using western blotting. The results are expressed as a Bax/Bcl-2 ratio. $\mathrm{H}_{2} \mathrm{O}_{2}$ treatment considerably increased the $\mathrm{Bax} / \mathrm{Bcl}-2$ ratio, whereas $\mathrm{KA}(0.3$ and $1.0 \mu \mathrm{M})$ significantly reduced this $\mathrm{H}_{2} \mathrm{O}_{2}$-induced effect (Figure 2B). Similarly, the expression of CC3 considerably increased, 
whereas KA $(1 \mu \mathrm{M})$ significantly reversed this effect $\left(p<0.001\right.$ compared with $\mathrm{H}_{2} \mathrm{O}_{2}$ alone; $\mathrm{n}=3$ ) (Figure 2C).

A

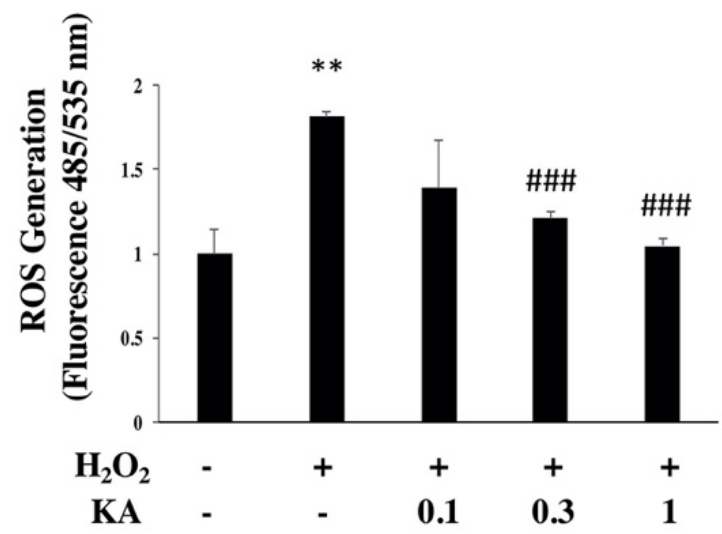

B

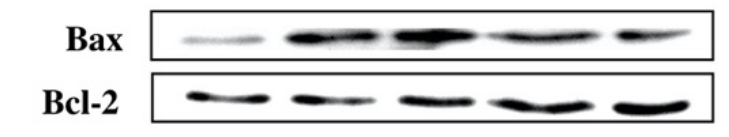

C
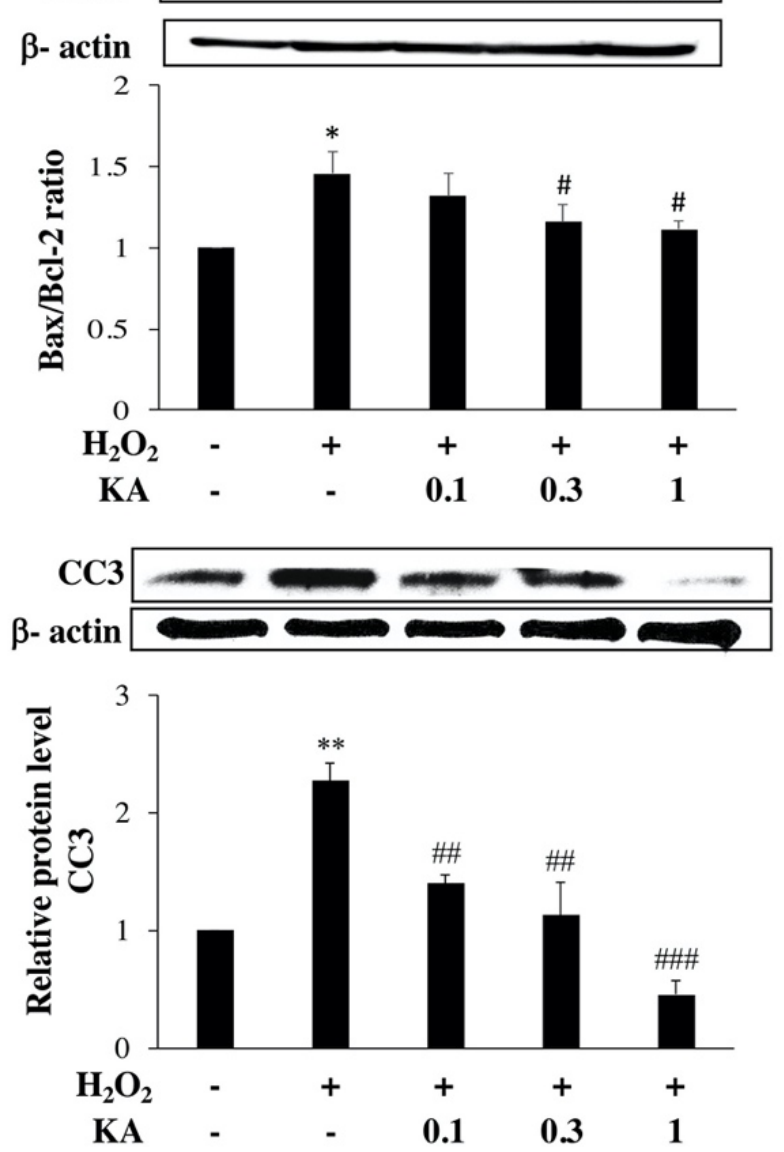

Figure 2. Effects of Kansuinine A (KA) on hydrogen peroxide $\left(\mathrm{H}_{2} \mathrm{O}_{2}\right)$-induced reactive oxygen species (ROS) generation, the $\mathrm{Bax} / \mathrm{Bcl}-2$ ratio, and cleaved caspase-3 (CC3) protein expression in human aortic endothelial cells (HAECs). HAECs were exposed to KA $(0.1,0.3$, and $1.0 \mu \mathrm{M})$ for $1 \mathrm{~h}$ before $\mathrm{H}_{2} \mathrm{O}_{2}(200 \mu \mathrm{M})$ treatment for $24 \mathrm{~h}$. (A) The cellular ROS/superoxide detection assay was performed. (B) Bax/Bcl-2 ratio. (C) CC3 expression was evaluated using western blotting. $\beta$-actin was used as an internal control. Data are presented as means \pm standard deviation $(\mathrm{n}=3) . p$ Values were determined using the Student's $t$-test. ${ }^{*} p<0.05,{ }^{* *} p<0.01$ vs. control group; $\# p<0.05$, $\# \# p<0.01$, \#\# $p<0.001$ vs. $\mathrm{H}_{2} \mathrm{O}_{2}$ group CC3, Cleaved caspase-3. 


\subsection{KA Inhibits $\mathrm{H}_{2} \mathrm{O}_{2}$-Induced HAEC Apoptosis via P-IKK $\beta, P-I \kappa B \alpha, P-N F-\kappa B$, and CC3}

We investigated the molecular mechanism to better understand how KA prevents $\mathrm{H}_{2} \mathrm{O}_{2}$-induced cell apoptosis. Expression levels of P-IKK $\beta$, P-IкB $\alpha$, P-NF- $\kappa B$ (p65), and CC3 in $\mathrm{H}_{2} \mathrm{O}_{2}$-treated HAECs were evaluated using western blotting. $\mathrm{H}_{2} \mathrm{O}_{2}$ treatment considerably increased expression levels of P-I $\kappa \mathrm{B} \alpha, \mathrm{P}-\mathrm{IKK} \beta$, and P-NF- $\kappa \mathrm{B}$ compared with controls $(p<0.05, p<0.01$, and $p<0.001$, respectively; $\mathrm{n}=3$ ). Conversely, KA significantly reduced the expression of P-IKK $\beta(p<0.01$ at $1.0 \mu \mathrm{M} \mathrm{KA}), \mathrm{P}-\mathrm{I} \kappa \mathrm{B} \alpha(p<0.05$ at $0.3 \mu \mathrm{M} \mathrm{KA}$ and $p<0.01$ at $1.0 \mu \mathrm{M} \mathrm{KA})$, and P-NF- $\mathrm{KB}(p<0.05$ at $0.3 \mu \mathrm{M}$ and $1.0 \mu \mathrm{M} \mathrm{KA})$ compared with $\mathrm{H}_{2} \mathrm{O}_{2}$ exposure alone $(\mathrm{n}=3$; Figure $3 \mathrm{~A})$. The $\mathrm{H}_{2} \mathrm{O}_{2}$-induced HAECs were also pre-treated with BMS-345541 (IKK inhibitor, $25 \mu \mathrm{M}$ ) or BAY 11-7082 (NF- $\mathrm{kB}$ inhibitor, $1.0 \mu \mathrm{M}$ ), and we found that $\mathrm{H}_{2} \mathrm{O}_{2}$ caused a significant increase in $\mathrm{CC} 3$ expression, which was completely reversed by BMS-345541 and BAY 11-7082 $(n=3$; Figure 3B). These findings suggest that $\mathrm{H}_{2} \mathrm{O}_{2}$ significantly increased CC 3 expression via the $\mathrm{IKK} \beta / \mathrm{I} \kappa \mathrm{B} \alpha / \mathrm{NF}-\mathrm{kB}$ pathway in HAECs (Figure 3C), and this effect was reversed by KA.

A

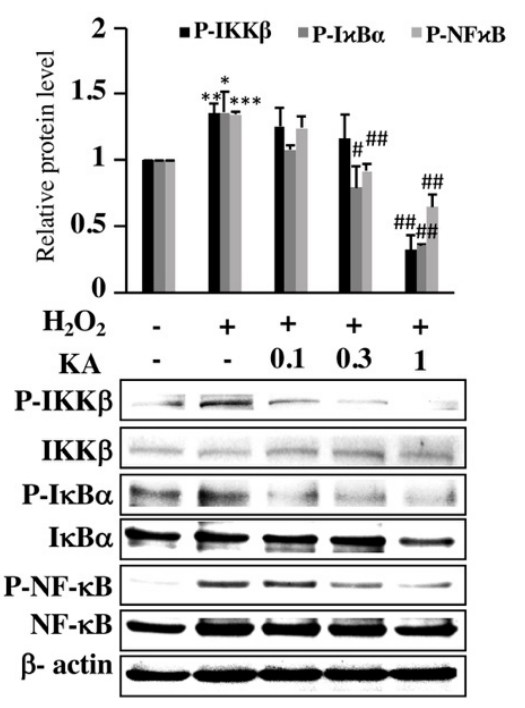

C

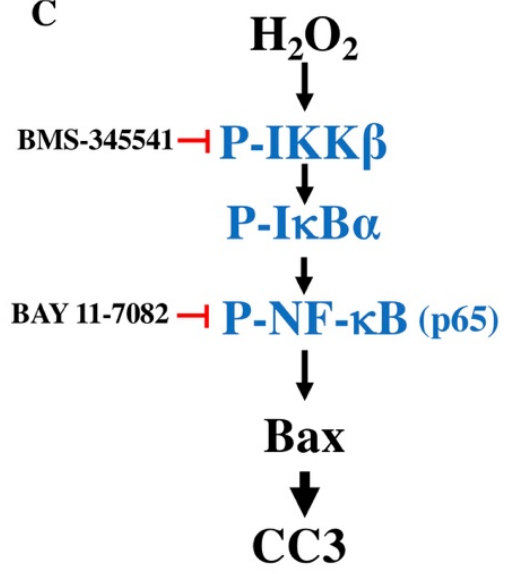

B

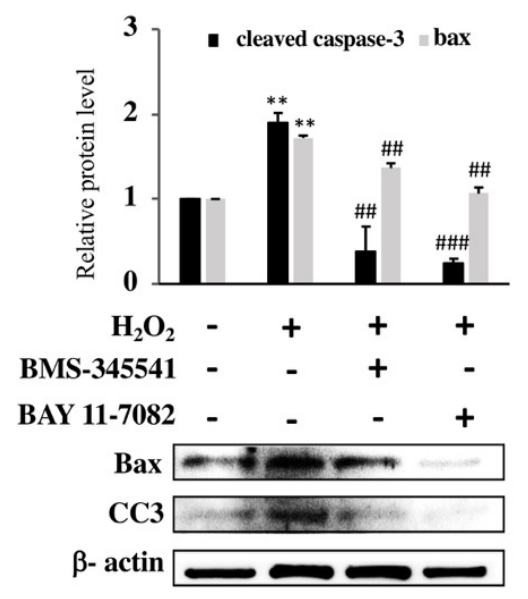

Figure 3. Mechanism of action of hydrogen peroxide $\left(\mathrm{H}_{2} \mathrm{O}_{2}\right)$ and Kansuinine A (KA). (A) Activation of P-IKK $\beta, P-I \kappa B \alpha$, and P-NF- $\kappa B$ (p65). Human aortic endothelial cells (HAECs) were pre-treated with 
KA $(0.1,0.3$, and $1.0 \mu \mathrm{M})$ for $1 \mathrm{~h}$ and were then exposed to $\mathrm{H}_{2} \mathrm{O}_{2}(200 \mu \mathrm{M})$ for $24 \mathrm{~h}$. Subsequently, western blotting was performed. (B) The expression of Bax and CC3 in the presence or absence of BMS-345541 $(25 \mu \mathrm{M})$ and BAY 11-7082 $(1 \mu \mathrm{M})$. Data were quantified by determining the optical density of the bands. The bar graphs show the expression ratio of P-IKK $\beta, P-I \kappa B \alpha, P-N F-\kappa B(p 65), B a x$, and $\mathrm{CC} 3$ relative to that of $\beta$-actin, which was normalized to 1 . Data are presented as means \pm standard deviation, $\mathrm{n}=3, p$ values were determined using the Student's $t$-test. ${ }^{*} p<0.05,{ }^{* *} p<0.01,{ }^{* * *} p<0.001$ vs. control group; \# $p<0.05$, \#\# $p<0.01$, \#\#\# $p<0.001$ vs. $\mathrm{H}_{2} \mathrm{O}_{2}(200 \mu \mathrm{M})$ group. (C) Working model of $\mathrm{H}_{2} \mathrm{O}_{2}$-induced apoptosis. Black arrow = stimulation; red line with end bar = inhibition.

\subsection{KA Reduces the Formation of Atherosclerotic Lesions and the Levels of Apoptosis-Related Proteins in $\mathrm{ApoE}^{-/-}$Mice}

ROS-induced vascular endothelial cell damage is an essential risk factor for the pathogenesis of atherosclerosis $[4,20,21]$. To further study the effects of KA on the development of atherosclerotic lesions in $A p o E^{-/-}$mice, the most popular murine model used for atherosclerotic studies, the bodyweight of the $A p o E^{-/-}$mice treated with 20 or $60 \mu \mathrm{g} / \mathrm{kg} \mathrm{KA}$ was found to be significantly lower compared with that of mice in the HFD group (Figure $4 A, B ; p<0.001$ ). The serum total-cholesterol, low-density lipoprotein (LDL)-cholesterol, and triglyceride levels of 20 and $60 \mu \mathrm{g} / \mathrm{kg}$ KA-treated groups were significantly lower in $A p o E^{-/-}$mice than in HFD mice $(p<0.05)$, while the HDL-C levels of the $60 \mu \mathrm{g} / \mathrm{kg} \mathrm{KA}$-treated group were significantly higher in $A p o E^{-/-}$mice than in HFD mice (Figure $4 \mathrm{C}$ ). These results demonstrate that KA effectively ameliorates the serum biochemical parameters. Moreover, we used Oil Red O staining to examine lesions in the aortas of $A p o E^{-/-}$mice. After the administration of KA, the aortic arch assay was performed to evaluate lesion formation. In $A p o E^{-/-}$mice fed the HFD for 15 weeks, the atherosclerotic lesion was larger than that in wild-type (WT) mice $(p<0.001$; Figure 4 C). However, the atherosclerotic lesion area was considerably lower in HFD-fed ApoE $E^{-1-}$ mice supplemented with $20 \mu \mathrm{g} / \mathrm{kg} \mathrm{KA}(23 \%$ reduction, $p<0.05)$ and $60 \mu \mathrm{g} / \mathrm{kg} \mathrm{KA}(61 \%$ reduction, $p<0.001$ ) (Figure $4 \mathrm{D}, \mathrm{E}$ ) than in HFD-fed mice not supplemented with KA. In addition, we also used hematoxylin and eosin (H\&E) staining for cross-sections of the aorta. ApoE $E^{-/-}$mice administered KA demonstrated a significant attenuation of aortic plaque formation in comparison with untreated mice. The plaque area was reduced by KA treatment in a dose-dependent manner (Figure $5 \mathrm{~A}$ ). At the $60 \mu \mathrm{g} / \mathrm{kg}$ dose, KA almost completely abrogated plaque formation in comparison with untreated $A p o E^{-/-}$mice. Furthermore, we found that mRNA expression of Bax and caspase 3 and protein expression of Bax and CC 3 were reduced by KA treatment in aortic tissues (Figure $5 B, C$ ). Together, these results suggest that KA attenuated the size of atherosclerotic lesions.

\subsection{KA Modulates the Expression Levels of Glutathione Peroxidase (GPx) and Malondialdehyde (MDA)}

Oxidative stress and oxidative tissue injury markers were evaluated to determine whether KA protects against oxidative cell damage. Levels of the antioxidant enzyme glutathione peroxidase (GPx) were significantly reduced in the aorta of $A p o E^{-/-}$HFD-fed mice, compared with levels observed in WT mice (Figure 6A; $p<0.001$ ). ApoE ${ }^{-/-}$mice fed an HFD, along with KA20 or KA60, showed significantly higher levels of GPx than mice from the $A p o E^{-/-}$HFD group (Figure $6 \mathrm{~A} ; p<0.001$ ). Moreover, in vitro, $\mathrm{H}_{2} \mathrm{O}_{2}$ treatment decreased the levels of GPx (fold-change relative to control) (Figure 6B; $p<0.01$ ) in HAECs. Conversely, GPx levels increased significantly upon treatment with KA (Figure 6B; $p<0.001$ at $1.0 \mu \mathrm{M} \mathrm{KA}$ ). Moreover, levels of the lipid peroxidation marker malondialdehyde (MDA) were significantly elevated in the $A p o E^{-/-}$HFD group, compared with that in the WT group (Figure 6C; $p<0.001$ ). MDA levels in $A p o E^{-1-}$ mice fed an HFD, along with KA20 or KA60, were significantly lower than those in mice from the $A p o E^{-/-}$HFD group (Figure $6 C ; p<0.001$ ). 
A $\mathrm{WT}(\mathrm{CD})$

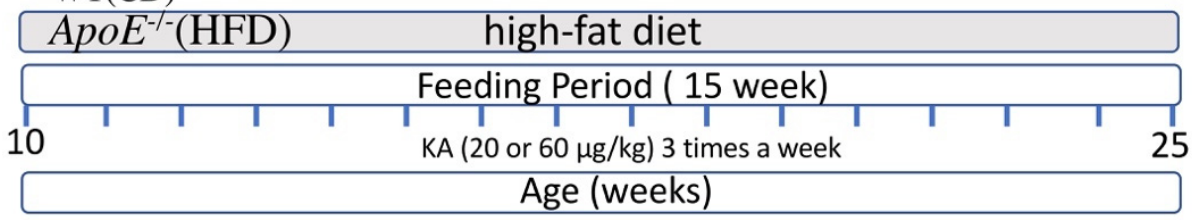

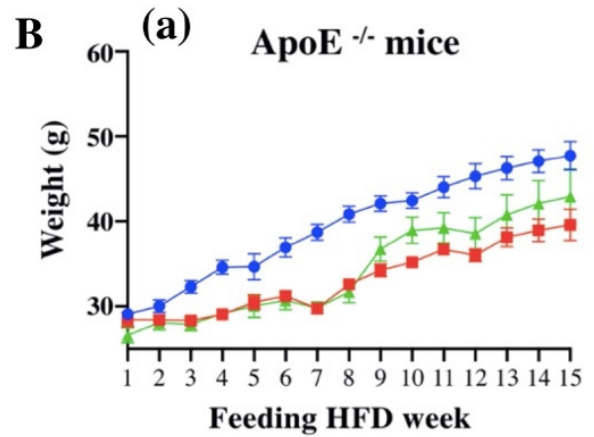

C

(a)

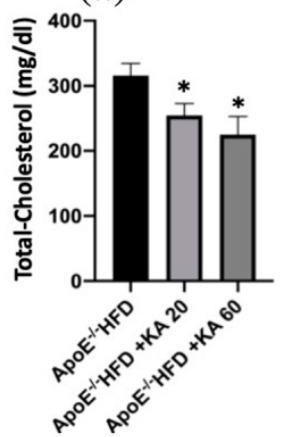

D
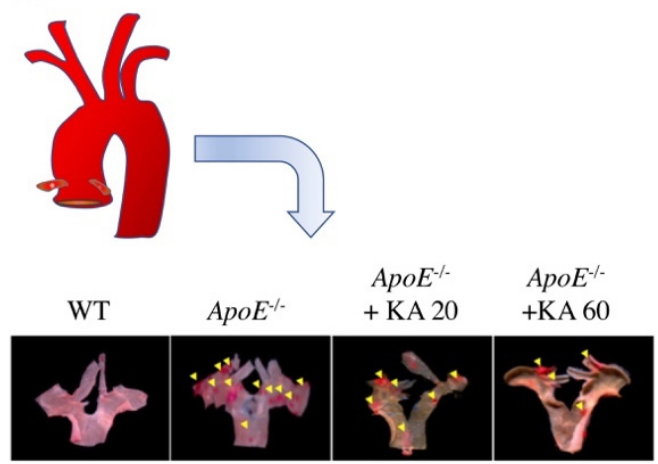

(b)

-ApoE $\%$ HFD-only

- - ApoE $\%$ HFD+KA 20

$\triangle$ ApoE $\%$ HFD+KA 60

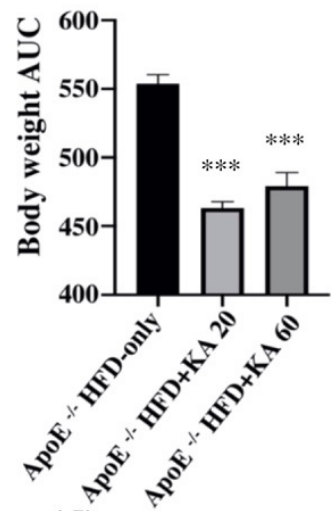

(c)

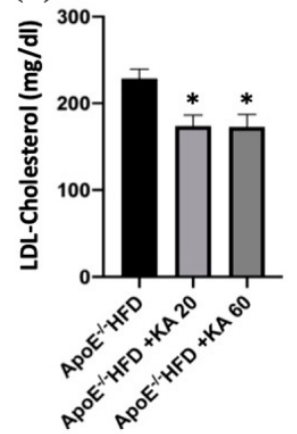

(d)

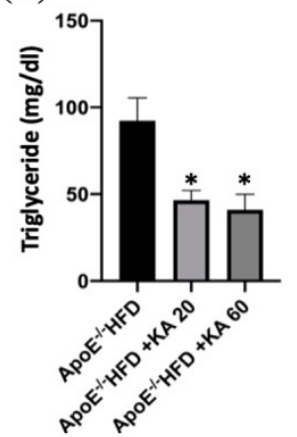

E

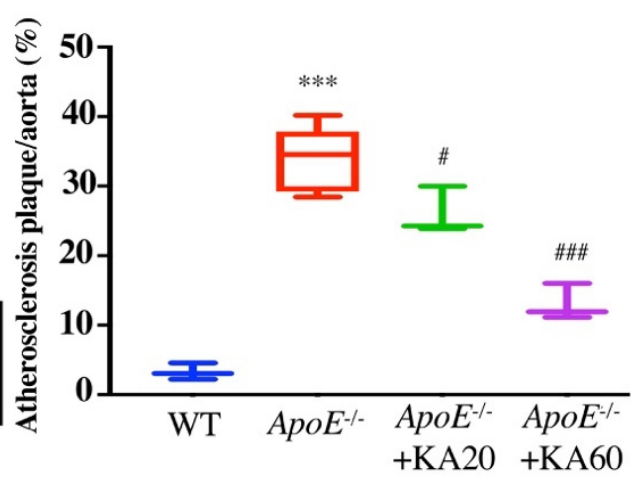

Figure 4. Kansuinine A (KA) reduces atherosclerosis development in $A p o E^{-/-}$mice. (A) Work scheme. Briefly, C57BL/6 (WT) mice received a normal chow diet (CD) or $A p o E^{-/-}$mice received a high-fat diet (HFD) or $A p o E^{-/-}$mice received an HFD supplemented with 20 or $60 \mu \mathrm{g} / \mathrm{kg}$ KA per g of body weight three times a week for 15 weeks. (B) Mouse body weight was recorded during the 15 week study period. Body weight curves (a) and Area Under the Curve values for body weight (g) (b). ApoE $E^{-/-}$mice were fed with a high-fat diet (HFD) or maintained on HFD supplemented with $20 \mathrm{or} 60 \mu \mathrm{g} / \mathrm{kg}$ of KA per g of body weight, three times a week for 15 weeks. Area Under the Curve values for the body weight were monitored each week. All data are presented as the means \pm SD; statistical analyses were performed using analysis of variance (one-way ANOVA or the Student's $t$-test), $\mathrm{n}=5$; ${ }^{* * *} p<0.001$ vs. HFD group. (C) Lipid profiles measured at the end 
of the study period. The plasma lipid profile in $A p o E^{-/-}$mice fed an HFD or those supplemented with 20 or $60 \mu \mathrm{g} / \mathrm{kg} \mathrm{KA}$ per $g$ of body weight, three times a week for 15 weeks. (a) Total-cholesterol (TC), (b) HDL-cholesterol, (c) LDL-cholesterol, and (d) Triglyceride (TG) levels. All data are presented as the means \pm SD; statistical analyses were performed using analysis of variance, $\mathrm{n}=5 ;^{*} p<0.05$, vs. HFD group. (D) Representative aortas from mice in each group stained with Oil Red O. (E) En face lesion areas (\%) in the aortic arches of wild-type (WT) and $A p o E^{-/-}$mice treated with or without KA. The en face luminal aortic surface in WT mice and $A p o E^{-1-}$ mice fed the HFD, or HFD supplemented with 20 or $60 \mu \mathrm{g} / \mathrm{kg} \mathrm{KA}$ (20 KA+HFD and $60 \mathrm{KA}+\mathrm{HFD}$ ) for 15 weeks ( $\mathrm{n}=5$ per group). Data represent the mean ratio of plaque area over the total aortic luminal area and are expressed as means \pm standard deviation. $p$ Values were determined using one-way analysis of variance (ANOVA) followed by Scheffé's method. ${ }^{* * *} p<0.001$ vs. WT group; $\# p<0.05$, \#\#\# $p<0.001$ vs. HFD group.
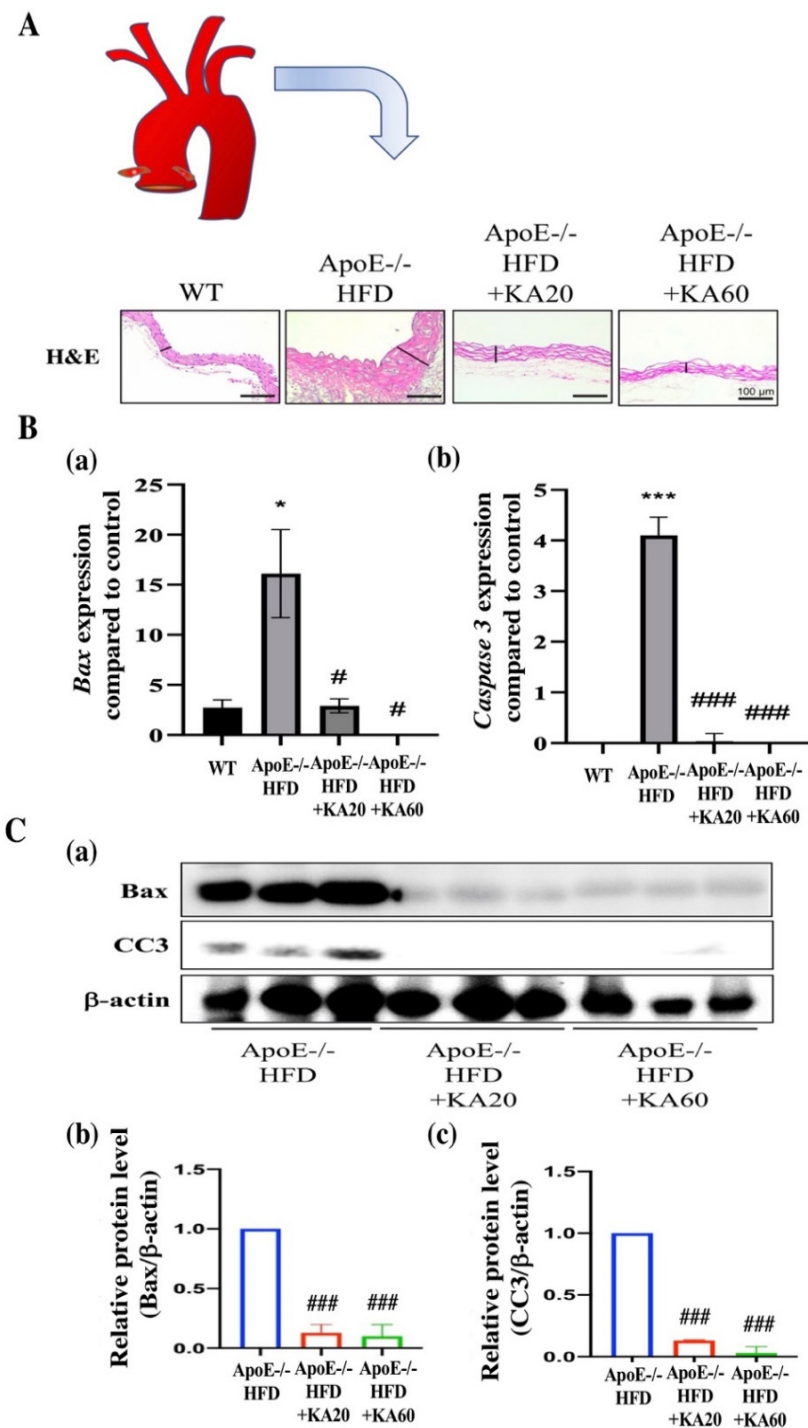

Figure 5. Kansuinine A (KA) reduces atherosclerotic lesions. Results showing the mRNA and protein expression of Bax and caspase-3 in $A p o E^{-/-}$mice. $A p o E^{-/-}$mice fed a high-fat diet (HFD) or HFD supplemented with 20 or $60 \mu \mathrm{g} / \mathrm{kg}$ KA (20 KA+HFD and $60 \mathrm{KA}+\mathrm{HFD}$, respectively) per g of body weight three times a week for 15 weeks. (A) Hematoxylin and eosin (H\&E) staining of representative atherosclerotic lesions in aortic root from WT and $A p o E^{-/-}$mice. Lesion width of aortic root highlighted with black. Scale bars, $100 \mu \mathrm{m}$. (B) mRNA expression of Bax (a) and caspase-3 (b) were evaluated using RT-qPCR. (C) Protein expression of Bax (b) and cleaved caspase-3 (CC3, c) were evaluated using western blotting (a). $\beta$-actin was used as the control. Data are presented as means \pm standard deviation $(\mathrm{n}=3) . p$ Values were determined using the Student's $t$-test. ${ }^{*} p<0.05$, *** $p<0.001$ vs. WT mice; $\# p<0.05$, \#\#\# $p<0.001$ vs. ApoE ${ }^{-/-}$mice fed a high-fat diet (HFD group). 


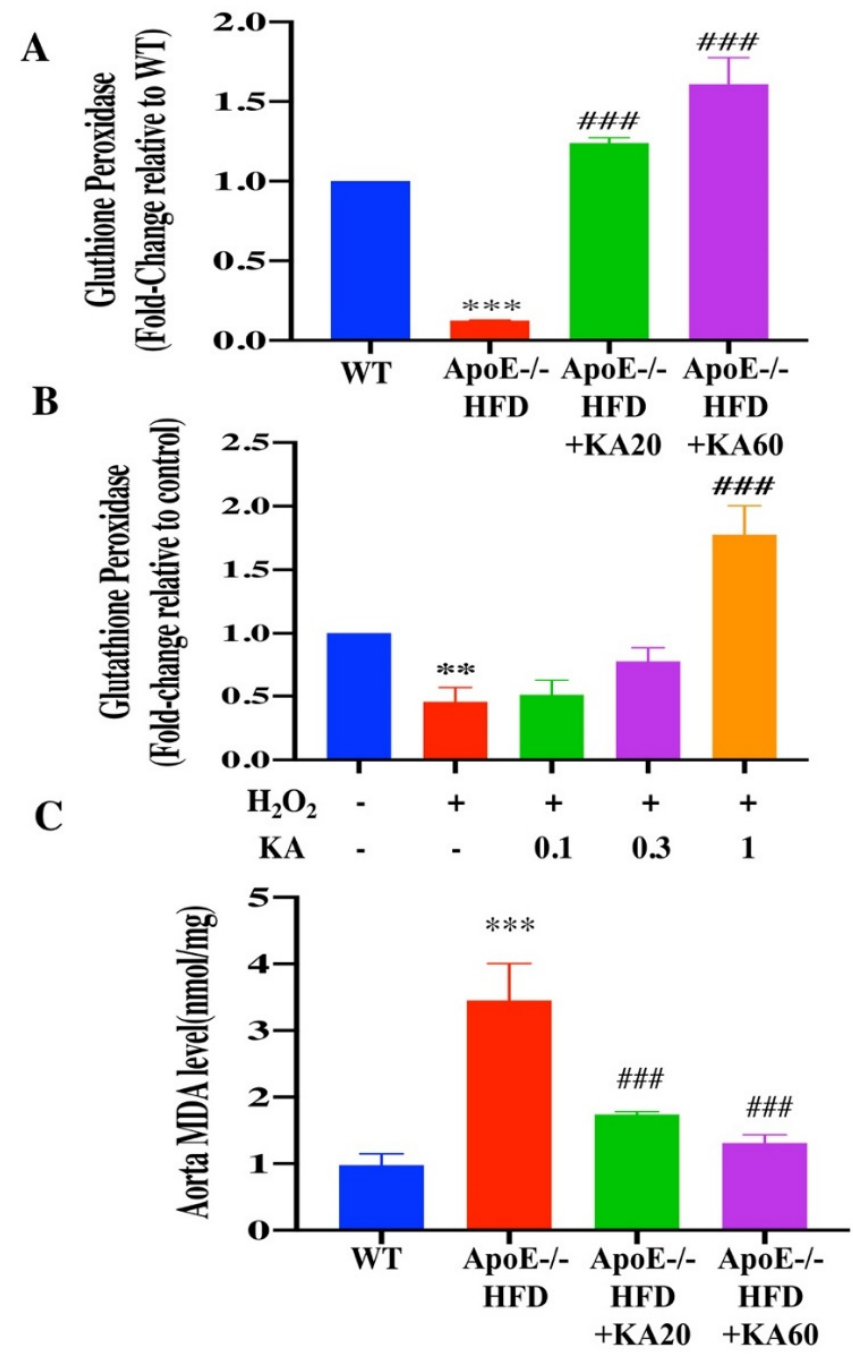

Figure 6. Effects of Kansuinine A (KA) on glutathione peroxidase (GPx) activity in vivo or in vitro and the aorta MDA level in mice. Activity of GPx was measured in (A) aortic tissue homogenates from mice in the different groups and (B) human aortic endothelial cells exposed to KA $(0.1,0.3$, and $1.0 \mu \mathrm{M})$ for $1 \mathrm{~h}$ before $\mathrm{H}_{2} \mathrm{O}_{2}(200 \mu \mathrm{M})$ treatment for $24 \mathrm{~h}$. Data are presented as the means \pm standard deviations $(\mathrm{n}=5)$. $p$ Values were determined using the Student's $t$-test. ${ }^{* *} p<0.01,{ }^{* * *} p<0.001$ vs. WT or control group; $\# \#$ \# $<0.001$ vs. $A p o E^{-/-}$mice fed a high-fat diet (HFD) or cells from the $\mathrm{H}_{2} \mathrm{O}_{2}$ group. (C) MDA levels in aorta of mice. $A p o E^{-/-}$mice fed an HFD or maintained on an HFD supplemented with $20 \mathrm{or} 60 \mu \mathrm{g} / \mathrm{kg}$ KA per $\mathrm{g}$ of body weight three times a week for 15 weeks. Data are presented as the means \pm standard

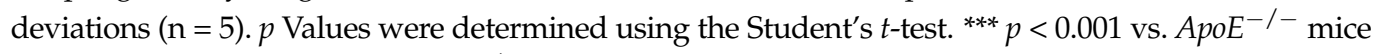
fed an HFD. \#\# $p<0.001$ vs. ApoE $E^{-/-}$mice fed an HFD.

\section{Discussion}

It is well known that endothelial dysfunction caused by ROS is one of the major mechanisms of CVD development [21]. The inhibition of ROS-induced endothelial cell damage is beneficial in preventing CVDs and atherosclerosis. Therefore, an approach (combining the measurement of intracellular ROS levels, western blotting, apoptotic cell staining, and aortic arch assays) was developed to screen anti-atherogenic drugs. Based on the screening platform, the findings of the present study indicate that KA protects HAECs from ROS-induced cellular damage. Moreover, this effect may be mediated by a decreased $\mathrm{Bax} / \mathrm{Bcl}-2$ ratio and phosphorylation of $\mathrm{IKK} \beta, \mathrm{I} \kappa \mathrm{B} \alpha, \mathrm{NF}-\mathrm{kB}$, and $\mathrm{CC} 3$. In addition, the findings showed that atherogenic changes in the aortas of $A p o E^{-/-}$mice can be prevented by KA (Figure 7). 


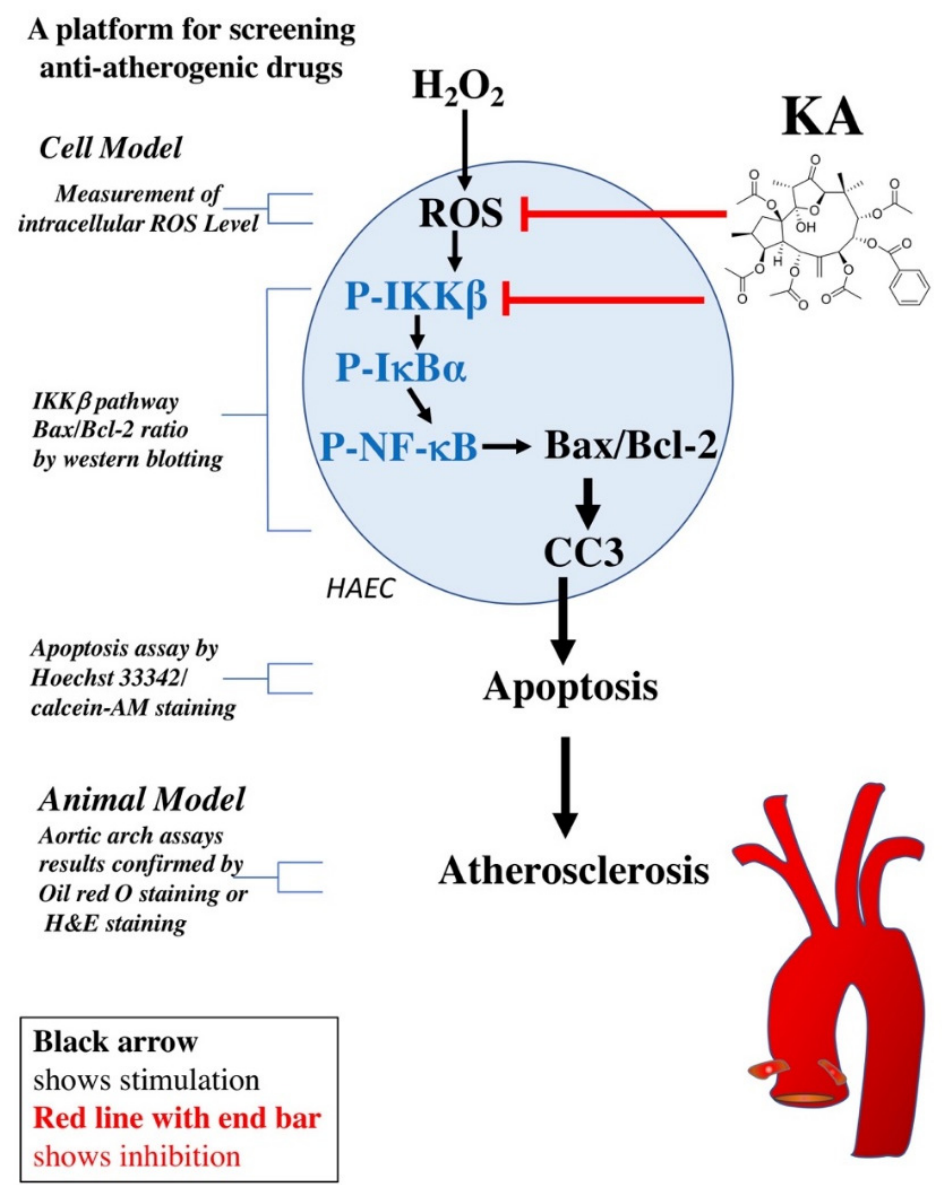

Figure 7. A platform for screening anti-atherogenic drugs and Kansuinine A against hydrogen peroxide-mediated cell apoptosis and atherosclerosis. The black arrow indicates stimulation, and the red line with an end bar indicates inhibition.

Hydrogen peroxide, an ROS, has been shown to play a major role in vascular and endothelial dysfunction [20]. Our findings corroborate those of previous studies indicating that $\mathrm{H}_{2} \mathrm{O}_{2}$ may produce intracellular ROS and inhibit cell viability, depending on its concentration [22]. Due to the importance of inflammation and oxidation pathways in atherosclerosis, nutraceuticals may be of great value to help reduce the risk from a macroscopic and pathophysiological perspective [23]. Moreover, herbs have been widely used to treat diseases in several Asian countries [7,9]. There is sufficient evidence that several herbs have significant antioxidant properties [15]. KA is an anthraquinone compound extracted from $E$. kansui with ethyl acetate; our findings showed that $\mathrm{KA}$ inhibits $\mathrm{H}_{2} \mathrm{O}_{2}$-induced intracellular ROS generation and that $3 \mu \mathrm{M} \mathrm{KA}$ is not harmful to cells.

There are many enzymes involved in ROS production, including NADPH oxidase (NOX), mitochondrial electron transport chain (ETC), xanthine oxidase, uncoupled endothelial nitric oxide synthase (eNOS), cytochrome P-450 oxygenase, cyclooxygenase, and oxygenase. Vascular NOX subtypes (Nox1, Nox2, Nox4, and Nox5) differ in their activity and cell specificity in response to agonists, growth factors, and hypoxia, and the types of ROS released after activation [24]. Imbalanced ROS homeostasis leads to oxidative stress, leading to direct cell damage, and destruction of the ROS signal transduction mechanism will exacerbate this damage [25]. Moreover, ROS-mediated cell injury occurs mainly via DNA damage and apoptosis [21,26]. Therefore, to assess $\mathrm{H}_{2} \mathrm{O}_{2}$-induced apoptosis and the inhibitory effect of $\mathrm{KA}$ on $\mathrm{H}_{2} \mathrm{O}_{2}$, we performed Hoechst fluorescence staining [10]. Under the action of $\mathrm{H}_{2} \mathrm{O}_{2}$, the damaged DNA was stained and produced strong fluorescence. Additionally, calcein-AM live-cell staining can also be used to observe damaged cells that 
produce strong fluorescence under the action of $\mathrm{H}_{2} \mathrm{O}_{2}$; this effect can be inhibited by KA at various concentrations, and the inhibitory effect is proportional to the dose of KA [27].

Furthermore, KA may inhibit cell apoptosis [28]. Several apoptosis-related proteins regulate cell survival, including Bax, Bcl-2, and CC3 $[10,29,30] . \mathrm{H}_{2} \mathrm{O}_{2}$ causes cell death via the apoptosis pathway, and this can be confirmed by the protein expression of Bax (pro-apoptotic protein) and Bcl-2 (anti-apoptotic protein) and the Bax/Bcl-2 ratio [30]. Experimental results showed that KA reduces the expression of Bax and the Bax/Bcl-2 ratio, eventually decreasing cell apoptosis. In addition, Nrf2 and NF- $\kappa B$ are key pathways closely associated with oxidative stress and inflammation [12]. NF- $\mathrm{KB}$ is a central mediator of inflammation, and its signaling is considered to be a master regulator of the inflammatory response and inflammation-related diseases [12,31,32]. Although IKK $\beta, \operatorname{I\kappa B} \alpha$, and NF- $\kappa B$ are inflammatory factors, they are also involved in the apoptosis pathway [32,33]. Our results suggest that this may be mediated by reducing the phosphorylation of $\operatorname{IKK} \beta, \operatorname{IKB} \alpha$, and NF- $\kappa$ B. Moreover, anti-inflammatory drugs can also reduce cell apoptosis caused by ROS [34]. Cell survival regulation requires several apoptosis-related proteins, including IKK $\beta$, I $\kappa \mathrm{B} \alpha, \mathrm{NF}-\mathrm{k} B$, and $\mathrm{CC} 3$. Our experiments verified that KA reduces the expression of these proteins, which enhances the apoptosis pathway following $\mathrm{H}_{2} \mathrm{O}_{2}$ stimulation, and increases the inhibitory effect at increased concentrations. $\mathrm{H}_{2} \mathrm{O}_{2}$ increased the concentration of IKK $\beta, \operatorname{I\kappa B} \alpha$, and NF- $\kappa B$, and the Bax/Bcl-2 ratio, leading to caspase- 3 cleavage and apoptosis, whereas KA pre-treatment inhibited $\mathrm{H}_{2} \mathrm{O}_{2}$-induced apoptosis [35,36].

Vascular endothelial cell exposure to ROS leads to cell damage followed by atherosclerosis [4]. Studies have also shown that $\mathrm{H}_{2} \mathrm{O}_{2}$ can cause vasodilation in mice [37]. Recent antioxidant interventions have been established using synthetic and naturally occurring molecules as adjuvant strategies for lipid reduction or anti-inflammatory therapies, aimed at reducing the risk of CVDs $[21,26]$. In the present study, we further confirmed that KA substantially decreased the size of atherosclerotic lesions. According to the results of several previous studies, malondialdehyde (MDA) is one of the most frequently used indicators of lipid peroxidation. The MDA levels showed a positive correlation with the major CVD risk factors. In our study, it was found that the MDA level in the aorta of $A p o E^{-/-}$HFD-fed mice was significantly higher than that in the aortas of WT mice (Figure $6 \mathrm{C} ; p<0.001$ ). However, MDA levels in ApoE ${ }^{-/-}$mice fed an HFD, along with KA20 or KA60, were significantly lower than those in mice from the $A p o E^{-/-}$HFD group (Figure $6 C ; p<0.001$ ). Thus, the KA-mediated inhibition of ROS generation in vivo may partially be attributed to KA's free radical-scavenging activity. In addition, we also attempted to replicate the molecular experiments of KA as an inhibitor of the P-IKK $\beta / \mathrm{p} 65 /$ Bax/cleaved caspase-3 (CC3) pathway in $A p o E^{-/-}$mouse tissue and aortic sections. We found that mRNA expression of Bax and caspase 3 and the protein expression of Bax and CC 3 were reduced by KA treatment in aortic tissues, as we found in in vitro cell experiments (Figure 5B,C). However, KA decelerates the accumulation of lipid/plaque in mice, and the underlying mechanism has not been fully clarified, because the development of atherosclerosis is complicated. In atherosclerosis, leukocytes and platelets enhance the interaction with endothelial cells by the upregulation of cell adhesion molecules. In addition, the phenotypic vascular smooth muscle cells (VSMCs) undergo enhanced proliferation, migration, and invasion, thereby narrowing the arterial lumen and inducing angiotensin dysregulation [38]. In particular, VSMCs can proliferate and synthesize extracellular matrix and secrete adhesion molecules, thereby recruiting and stabilizing inflammatory cells and absorbing lipids, and promoting the formation of foam cells, leading to the development of atherosclerotic lesions [39]. Hence, atherosclerosis can be described as an immune disease that is activated via the inflammatory pathway. Herbal preparations can suppress pathological immune responses and can regulate the progression of atherosclerosis [40]. A detailed investigation is needed to clarify whether KA can modulate the diameter of blood vessels, regulate blood pressure, and improve blood flow, as well as elucidate the role of immune cells.

In addition to $\mathrm{H}_{2} \mathrm{O}_{2}$-induced $\mathrm{ROS}$, other stimuli (such as high concentrations of glucose and atherogenic LDL) exhibit similar effects [41]. According to the results of existing 
clinical trials, natural products can be used as adjuvant therapeutics to reduce the level of small dense LDL and the number of LDL particles, increase the size of LDL, and, thereby, prevent CVD [42]. In turn, oxidized LDL can activate abnormal endothelial cells, thereby exposing cell adhesion molecules (VCAM-1 and ICAM-1) that bind and recruit inflammatory leukocytes (T cells and monocytes) to the subendothelial space [43]. Therefore, diseases related to diabetes and dyslipidemia, as well as treatments of these diseases, can also be further investigated using this platform. In addition, because mitochondria are an important source of ROS and contribute to oxidative stress in cells under pathologic conditions, in preliminary studies, we also found that mitochondrial function/structure is impaired in HAECs treated with $\mathrm{H}_{2} \mathrm{O}_{2}$. However, Kansuinine A may improve $\mathrm{H}_{2} \mathrm{O}_{2}-$ induced mitochondrial dysfunction.

There are many related enzymes (such as NOX, catalase, and glutathione peroxidase) involved in the production of ROS. With regard to the effects of KA in protecting cells from oxidative stress, as mediated by antioxidant enzymes, we found that the level of GPx (fold-change) in the aortas from the $A p o E^{-/-}$HFD-fed mice was significantly lower than that in the aortas from the WT mice (Figure 6A; $p<0.001$ ). Conversely, GPx activity was significantly lower in the $A p o E^{-/-}$mice fed an HFD, along with KA20 or KA60 (Figure $6 \mathrm{~A} ; p<0.001$ ). Moreover, $\mathrm{H}_{2} \mathrm{O}_{2}$ treatment considerably decreased GPx levels (foldchange relative to control) (Figure 6B; $p<0.01$ ) in HAECs. However, GPx levels increased significantly upon treatment with KA (Figure $6 \mathrm{~B} ; p<0.001$ at $1.0 \mu \mathrm{M} \mathrm{KA}$ ). Furthermore, we verified that KA exerts a protective effect on HAECs by reducing the effect of ROS. Whether KA has the same protective effect in the presence of other stress-inducing molecules, such as reactive oxygen-nitrogen species, hormones, and other drugs, must be assessed further. Future studies are also warranted to explore other mechanisms of KA.

\section{Materials and Methods}

\subsection{Reagents and Antibodies}

KA (HPLC purity $>98 \%$; Figure $1 \mathrm{~A}$ ) was purchased from Aobious (Gloucester, MA, USA). $\mathrm{H}_{2} \mathrm{O}_{2}$, dimethyl sulfoxide (DMSO), and BMS-345541 were purchased from SigmaAldrich (Merck KGaA, Darmstadt, Germany). Trypan blue and fetal bovine serum were purchased from Corning (Manassas, VA, USA) and Gibco (Auckland, New Zealand), respectively. 3-(4,5-Dimethylthiazol-2-yl)-2,5-diphenyltetrazolium bromide (MTT) and cellular ROS/Superoxide detection assay kit were purchased from Merck KGaA and Abcam (Cambridge, MA, USA), respectively. Anti-Phospho-IKK $\beta$, anti-Phospho-IkB $\alpha$, anti-Phospho-NF- $\mathrm{kB}$ (p65), and anti-cleaved caspase-3 antibodies were obtained from Cell Signaling Technology (Danvers, MA, USA). Anti- $\beta$-actin antibodies were obtained from Sigma-Aldrich. BAY 11-7082 was procured from Calbiochem (La Jolla, CA, USA). All other reagents and chemicals were of analytical grade.

\subsection{HAEC Culture}

The HAEC line was isolated from the human ascending and descending aorta (PromoCell GmbH, Heidelberg, Germany). The cells were cultured in an endothelial cell growth medium at $37^{\circ} \mathrm{C}$ in a humidified atmosphere of $5 \% \mathrm{CO}_{2}$. During cell culture, the medium was changed every three days until the cells reached $90 \%$ confluence. To assess the effects of KA on HAECs, the cells were treated with increasing concentrations of KA $(0.1,0.3$, and $1.0 \mu \mathrm{M})$ for $1 \mathrm{~h}$, and then with $\mathrm{H}_{2} \mathrm{O}_{2}(200 \mu \mathrm{M})$ or vehicle for $24 \mathrm{~h}$ unless stated otherwise [10].

\subsection{Measurement of Cell Viability}

The MTT assay was used to determine cell viability. The cells, at a density of $1.0 \times 10^{5}$ cells/well, were seeded in a 96-well plate and allowed to attach for $24 \mathrm{~h}$. Thereafter, the culture supernatant was removed, and the cells were incubated with the MTT solution $(5 \mathrm{mg} / \mathrm{mL})$ supplemented with endothelial cell growth medium at $37^{\circ} \mathrm{C}$ for $4 \mathrm{~h}$. Subsequently, we replaced the dye-containing medium with $150 \mu \mathrm{L}$ DMSO and agitated 
the plate using a plate shaker for $5 \mathrm{~min}$. The optical density of the sample in each well was measured using a microplate reader (Infinite M1000; TECAN, Mechelen, Belgium) at $560 \mathrm{~nm}$. Cell viability is expressed as a percentage relative to the control [28].

\subsection{Apoptotic Cell Staining}

Hoechst 33342 (Molecular Probes, Eugene, OR, USA) and calcein acetoxymethyl ester (calcein-AM, Molecular Probes) staining were used to assess chromosomal breakage and cell membrane integrity, respectively. HAECs were pre-treated with vehicle $(0.1 \% \mathrm{DMSO})$ or $\mathrm{KA}(0.1,0.3$, or $1.0 \mu \mathrm{M})$ for $30 \mathrm{~min}$ and incubated with or without $\mathrm{H}_{2} \mathrm{O}_{2}(200 \mu \mathrm{M})$ for $24 \mathrm{~h}$. The treated cells were stained with $1.0 \mu \mathrm{M}$ Hoechst 33342 and calcein-AM for $10 \mathrm{~min}$. An Olympus IX70 inverted microscope (Olympus Corporation, Center Valley, PA, USA) was used for fluorescence imaging, and the apoptotic cells were quantified according to a previously described method [10].

\subsection{Measurement of Intracellular ROS Levels}

Intracellular ROS levels were determined using the Cellular ROS Assay Kit (ab113851) according to the manufacturer's instructions. Briefly, the cells $\left(1.0 \times 10^{5}\right.$ cells/well $)$ were seeded in a 96-well plate and allowed to attach for $24 \mathrm{~h}$. Thereafter, the culture supernatant was removed, and the cells were washed with $1 \times$ assay buffer $(100 \mu \mathrm{L} /$ well). DCFH-DA, an ROS-specific staining agent, was added to the cells, and the plate was incubated for $60 \mathrm{~min}$ in the dark. After incubation, the intracellular ROS levels were measured using a fluorescence microplate reader (Infinite M1000; TECAN) $(E x=488 \mathrm{~nm}, \mathrm{Em}=520 \mathrm{~nm}$ ).

\subsection{Western Blotting}

HAECs were culture in six-well plates at a density of $1.0 \times 10^{6}$ cells $/$ well and allowed to attach for $24 \mathrm{~h}$. HAECs were treated with vehicle, only $\mathrm{H}_{2} \mathrm{O}_{2}(200 \mu \mathrm{M} ; 24 \mathrm{~h})$, or $\mathrm{H}_{2} \mathrm{O}_{2}$ $(200 \mu \mathrm{M} ; 24 \mathrm{~h})$ and $\mathrm{KA}\left(0.1,0.3\right.$, and $1.0 \mu \mathrm{M} ; 1 \mathrm{~h}$ before adding $\left.\mathrm{H}_{2} \mathrm{O}_{2}\right)$. Thereafter, the HAECs were homogenized and lysed in the presence of a protease inhibitor (Roche Applied Science, Penzberg, Germany) in RIPA buffer (Thermo Fisher Scientific Inc., Waltham, MA, USA) to obtain the extracted protein. The protein sample was separated by sodium dodecyl sulfate-polyacrylamide gel electrophoresis (SDS-PAGE) (110 V, $90 \mathrm{~min})$. The separated proteins were transferred onto a polyvinylidene fluoride (PVDF) membrane and blocked with phosphate-buffered saline Tween-20 (PBST) supplemented with 5\% bovine serum albumin for $60 \mathrm{~min}$. Thereafter, the membranes were incubated with specific primary antibodies (1:1000), including Bax (Arigobio, Hsinchu, Taiwan), Bcl-2 (Arigobio), cleaved caspase-3 (CC3) (Cell Signaling Technology), and $\beta$-actin (1:10,000; Sigma-Aldrich), in PBST and incubated overnight at $4{ }^{\circ} \mathrm{C}$. The membranes were incubated with anti-rabbit horseradish peroxidase (HRP)-conjugated immunoglobulin G (IgG) (1:1000 in PBST; Gene Tex) for $60 \mathrm{~min}$ at $25^{\circ} \mathrm{C}$ to detect the binding of its corresponding antibody. Immunoreactive bands were detected with ECL Reagent (Millipore, Billerica, MA, USA). For the quantitative analysis of protein expression, the optical density of protein bands was analyzed by video densitometry (G-box Image System; Syngene, Frederick, MD, USA) [10].

\subsection{Lipid and Lipoprotein Profile}

Mice were fasted for 12-14 h before blood samples were collected. Serum was separated by centrifugation at $3000 \times g$ for $10 \mathrm{~min}$. Total cholesterol, triglyceride, verylow-density lipoprotein cholesterol, low-density lipoprotein cholesterol, and high-density lipoprotein cholesterol serum levels were enzymatically determined using commercial kits and the SPOTCHEM EZ SP-4430 automated analyzer (ARKRAY, Inc., Kyoto, Japan).

\subsection{Experiments with Mice and Oil Red O Staining of the Aortas}

Experiments with mice were approved by the China Medical University Institutional Animal Care and Use Committee (permit no. CMUIACUC-2019-094) and performed in accordance with the Guide for Care and Use of Laboratory Animals published by the U.S. 
National Institutes of Health (NIH Publication No. 85-23, revised 1996). Two species of mice were used to determine the effects of KA on atherosclerosis progression and divided into four groups ( $\mathrm{n}=5$ per group): (1) mice were maintained on a normal chow diet (CD); (2) apolipoprotein E knockout mice ( $A p o E^{-/-}$mice; from Jackson Laboratory, Sacramento, CA, USA) were fed a normal diet and HFD (TestDiet58Y1) for 15 weeks; and (3) and (4) mice were maintained on an HFD supplemented with 20 or $60 \mu \mathrm{g} / \mathrm{kg}$ KA per g of body weight, respectively, three times a week for 15 weeks. KA was administered via intraperitoneal injection. After the 15 week study period, the mice were anaesthetized and sacrificed by cervical dislocation, and the aortic arches were removed. Atherosclerotic plaques were visualized using Oil Red $\mathrm{O}$ staining. The aortic arches were fixed with $4 \%$ paraformaldehyde for $15 \mathrm{~min}$ and stained with $0.5 \%$ Oil Red O solution (Sigma-Aldrich) for $24 \mathrm{~h}$ [44]. The stained aortas were spread on a black board and photographed using a digital camera under identical light conditions with the same photography parameters. We calculated the area of the plaque divided by the area of the total blood vessels. Pictures were analyzed using Image J (Version 1.52a, NIH, Bethesda, MD, USA).

\subsection{Histological Investigations}

Mice were anesthetized and then euthanized by cervical dislocation. Subsequently, their thoracic aortas were excised. The aortic roots were fixed using $4 \%$ paraformaldehyde overnight and embedded in paraffin to obtain serial 3- $\mu$ m-thick sections. Every third slice in the series was stained using $\mathrm{H} \& \mathrm{E}$.

\subsection{RNA Isolation and Quantitative Real-Time PCR}

Tissues were snap-frozen in liquid nitrogen and stored at $-80^{\circ} \mathrm{C}$ until further processing. Total RNA from arteries was isolated using the NucleoZOL reagent (Macherey-Nagel GmbH \& Co., KG, Düren, Germany). Reverse transcription was conducted using the iScript gDNAClear cDNA synthesis kit (Bio-Rad, Hercules, CA, USA). Subsequently, quantitative real-time-PCR analyses were performed using the SensiFAST SYBR kit (BIO-98020, BioLin, Eveleigh, Australia) on the StepOnePlus real-time PCR system (Applied Biosystems, Life Technologies, Carlsbad, CA, USA) according to the manufacturer's instructions. The sequences of the primers used were: caspase-3, $5^{\prime}$-GCGAGTGAGAATGTGCATAAATTC- $3^{\prime}$ and $5^{\prime}$ GGGAAACCAACAGTACTCAGTCCT-3'; Bax 5' $^{\prime}$-GTTTCATCCA GGATCGAGCAG-3' and 5'-AGCTGAGCGAGTGTCTCCGGCG-3'; and GAPDH, 5' -AGAAGGCTGGGGCTCATTTG-3' and $5^{\prime}$-AGGGGCCATCCACAGTCTTC-3'. Relative gene expression was calculated using the delta delta CT method. The reactions were performed in duplicate.

\subsection{Western Blotting Analysis of the Tissues}

Tissue samples were mixed with $5 \times$ denaturing sample buffer, heated at $95{ }^{\circ} \mathrm{C}$ for $10 \mathrm{~min}$, and separated on a Bis-Tris discontinuous $4-12 \%$ polyacrylamide gradient gel (NuPAGE; Invitrogen). Proteins were then transferred to PVDF membranes and blocked with PBST supplemented with 5\% bovine serum albumin for $60 \mathrm{~min}$. Next, the membranes were incubated with specific primary antibodies (1:1000), including Bax (Santa Cruz Biotechnology), cleaved caspase-3 (CC3) (Cell Signaling Technology), and $\beta$-actin (1:10,000; Sigma-Aldrich), in PBST and incubated overnight at $4{ }^{\circ} \mathrm{C}$. The blots were incubated with anti-rabbit HRP-conjugated IgG (1:1000 in PBST; Gene Tex) for $60 \mathrm{~min}$ at $25^{\circ} \mathrm{C}$ to detect the binding of its corresponding antibody. Immunoreactive bands were detected using an ECL Reagent (Millipore, Billerica, MA, USA). For the quantitative analysis of protein expression, the optical density of protein bands was analyzed using video densitometry (G-box Image System; Syngene, Frederick, MD, USA).

\subsection{Measurement of Glutathione Peroxidase (GPx) and Malondialdehyde (MDA) Levels}

The activity of GPx in aortic tissues and HAECs were determined using Cayman chemicals kits, according to the manufacturer's instructions. GPx uses reduced glutathione's ability to reduce hydrogen peroxide. Glutathione reductase is used to regenerate reduced 
glutathione in the presence of NADPH. The decrease in NADPH absorbance that can be monitored at $340 \mathrm{~nm}$ is proportional to the GPx activity in the sample. The level of lipid peroxidation (MDA) in aortic tissue homogenates was evaluated using the thiobarbituric acid (TBA) test and lipid peroxidation (MDA) assay kit (abcam, ab118970). The MDA in the sample reacts with TBA to form the MDA-TBA adduct, which can be easily quantified spectrophotometrically at $532 \mathrm{~nm}$.

\subsection{Statistical Analysis}

All data are presented as a relative frequency for discrete responses and means \pm standard deviation for continuous responses. Statistical comparisons were performed using the Student's $t$-test or one-way analysis of variance (ANOVA), and Scheffé's method was used for intergroup comparisons. Results with $p$ values $<0.05$ were considered statistically significant.

\section{Conclusions}

The results indicated that $\mathrm{KA}$ inhibited $\mathrm{H}_{2} \mathrm{O}_{2}$-induced endothelial cell damage by directly reducing intracellular ROS generation. These protective effects involved the inhibition of the apoptosis cascade by inhibiting CC 3 activation and reducing the IKK $\beta$, $\mathrm{I} \kappa \mathrm{B} \alpha$, and NF- $\mathrm{K} \mathrm{B}$ phosphorylation levels. In vivo, KA reduced lipid accumulation and prevented atherogenic changes in the aortas of $\mathrm{ApoE}^{-/-}$mice. Thus, these findings provide novel insights into the preventive role of KA in the development of atherosclerosis and warrant additional studies regarding its potential use as a therapeutic agent.

Author Contributions: C.-S.C., B.-Y.P. and M.-Y.S. contributed to the conception and design of the methods used in this study, and performed the formal analysis; B.-Y.P., P.-H.T. and F.-Y.C. performed the investigation in this study; C.-S.C. and M.-Y.S. wrote the original draft of the manuscript; W.-C.Y. and M.-Y.S. reviewed and edited the manuscript and supervised the study. All authors have read and agreed to the published version of the manuscript.

Funding: This research was funded by the Ministry of Science and Technology of Taiwan (MOST1082320-B-039-034-MY3), China Medical University (CMU109-MF-70 and CMU110-MF-41), and China Medical University Hospital (DMR-106-118, DMR-108-127, and DMR-109-142).

Institutional Review Board Statement: Experiments with mice were approved by the China Medical University Institutional Animal Care and Use Committee (permit no. CMUIACUC-2019-094) and performed in accordance with the Guide for Care and Use of Laboratory Animals published by the US National Institutes of Health (NIH Publication No. 85-23, revised 1996).

Informed Consent Statement: Not applicable.

Data Availability Statement: The data presented in this study are available in article.

Conflicts of Interest: The authors declare no conflict of interest.

\section{References}

1. Wu, F.; Ma, Q.; Song, H.; Guo, X.; Diniz, M.A.; Song, S.S.; Gonzalez, N.R.; Bi, X.; Ji, X.; Li, D.; et al. Differential features of culprit intracranial atherosclerotic lesions: A whole-brain vessel wall imaging study in patients with acute ischemic stroke. J. Am. Heart Assoc. 2018, 7, e009705. [CrossRef]

2. Virani, S.S.; Alonso, A.; Aparicio, H.J.; Benjamin, E.J.; Bittencourt, M.S.; Callaway, C.W.; Carson, A.P.; Chamberlain, A.M.; Cheng, S.; Delling, F.N.; et al. Heart disease and stroke statistics-2021 update: A report from the American Heart Association. Circulation 2021, 143, e254-e743. [CrossRef]

3. Bermejo-Martin, J.F.; Martin-Fernandez, M.; Lopez-Mestanza, C.; Duque, P.; Almansa, R. Shared features of endothelial dysfunction between sepsis and its preceding risk factors (aging and chronic disease). J. Clin. Med. 2018, 7, 400. [CrossRef]

4. Li, J.M.; Shah, A.M. Endothelial cell superoxide generation: Regulation and relevance for cardiovascular pathophysiology. Am. J. Physiol. Regul. Integr. Comp. Physiol. 2004, 287, R1014-R1030. [CrossRef] [PubMed]

5. Redza-Dutordoir, M.; Averill-Bates, D.A. Activation of apoptosis signalling pathways by reactive oxygen species. Biochim. Biophys. Acta 2016, 1863, 2977-2992. [CrossRef]

6. Singh, S. Herbal approach for management of atherosclerosis: A review. Curr. Atheroscler. Rep. 2019, 21, 12. [CrossRef] 
7. Liu, C.; Huang, Y. Chinese herbal medicine on cardiovascular diseases and the mechanisms of action. Front. Pharmacol. 2016, 7, 469. [CrossRef]

8. Ekor, M. The growing use of herbal medicines: Issues relating to adverse reactions and challenges in monitoring safety. Front. Pharmacol. 2014, 4, 177. [CrossRef] [PubMed]

9. Tsai, F.J.; Cheng, C.F.; Chen, C.J.; Lin, C.Y.; Wu, Y.F.; Li, T.M.; Chuang, P.H.; Wu, Y.C.; Lai, C.H.; Liu, X.; et al. Effects of Chinese herbal medicine therapy on survival and hepatic outcomes in patients with hepatitis $\mathrm{C}$ virus infection in Taiwan. Phytomedicine 2019, 57, 30-38. [CrossRef] [PubMed]

10. Chen, W.Y.; Chen, F.Y.; Lee, A.S.; Ting, K.H.; Chang, C.M.; Hsu, J.F.; Lee, W.S.; Sheu, J.R.; Chen, C.H.; Shen, M.Y. Sesamol reduces the atherogenicity of electronegative L5 LDL in vivo and in vitro. J. Nat. Prod. 2015, 78, 225-233. [CrossRef] [PubMed]

11. Fusco, R.; Siracusa, R.; D'Amico, R.; Peritore, A.F.; Cordaro, M.; Gugliandolo, E.; Crupi, R.; Impellizzeri, D.; Cuzzocrea, S.; Di Paola, R. Melatonin Plus Folic Acid Treatment Ameliorates Reserpine-Induced Fibromyalgia: An Evaluation of Pain, Oxidative Stress, and Inflammation. Antioxidants 2019, 8, 628. [CrossRef]

12. Fusco, R.; Cordaro, M.; Siracusa, R.; D’Amico, R.; Genovese, T.; Gugliandolo, E.; Peritore, A.F.; Crupi, R.; Impellizzeri, D.; Cuzzocrea, S.; et al. Biochemical Evaluation of the Antioxidant Effects of Hydroxytyrosol on Pancreatitis-Associated Gut Injury. Antioxidants 2020, 9, 781. [CrossRef] [PubMed]

13. Al Disi, S.S.; Anwar, M.A.; Eid, A.H. Anti-hypertensive herbs and their mechanisms of action: Part I. Front. Pharmacol. 2015, 6, 323. [CrossRef]

14. Di Paola, R.; Fusco, R.; Gugliandolo, E.; D’Amico, R.; Campolo, M.; Latteri, S.; Carughi, A.; Mandalari, G.; Cuzzocrea, S. The Antioxidant Activity of Pistachios Reduces Cardiac Tissue Injury of Acute Ischemia/Reperfusion (I/R) in Diabetic Streptozotocin (STZ)-Induced Hyperglycaemic Rats. Front. Pharmacol. 2018, 9, 51. [CrossRef] [PubMed]

15. Huang, Y.; Yao, P.; Leung, K.W.; Wang, H.; Kong, X.P.; Wang, L.; Dong, T.T.X.; Chen, Y.; Tsim, K.W.K. The Yin-Yang property of Chinese medicinal herbs relates to chemical composition but not anti-oxidative activity: An illustration using spleen-meridian herbs. Front. Pharmacol. 2018, 9, 1304. [CrossRef]

16. Chai, Y.-S.; Hu, J.; Wang, X.-K.; Wang, Y.-G.; Xiao, X.-Y.; Cheng, X.-L.; Hua, L.; Lei, F.; Xing, D.-M.; Du, L.-J. Euphorbia kansui roots induced-diarrhea in mice correlates with inflammatory response. Chin. J. Nat. Med. 2013, 11, 231-239. [CrossRef]

17. Nunomura, S.; Kitanaka, S.; Ra, C. 3-o-(2,3-dimethylbutanoyl)-13-o-decanoylingenol from Euphorbia kansui suppresses igemediated mast cell activation. Biol. Pharm. Bull. 2006, 29, 286-290. [CrossRef]

18. Bao, B.H.; Yan, X.J.; Cao, Y.D.; Yao, W.F.; Cheng, F.F.; Chen, P.D.; Shan, M.Q.; Zhang, L.; Ding, A.W. Radix Kansui stir-fried with vinegar reduces Radix Kansui-related hepatotoxicity in mice via mitochondrial pathway. Chin. J. Integr. Med. 2021, 27, 192-197. [CrossRef]

19. Chang, J.S.; Lee, S.W.; Park, M.H.; Kim, M.S.; Hudson, B.I.; Park, S.J.; Lee, W.S.; Rho, M.C. Kansuinine a and kansuinine b from Euphorbia kansui L. inhibit IL-6-induced Stat3 activation. Planta Med. 2010, 76, 1544-1549. [CrossRef] [PubMed]

20. Breton-Romero, R.; Lamas, S. Hydrogen peroxide signaling in vascular endothelial cells. Redox. Biol. 2014, 2, 529-534. [CrossRef] [PubMed]

21. Cai, H.; Harrison, D.G. Endothelial dysfunction in cardiovascular diseases: The role of oxidant stress. Circ. Res. 2000, 87, 840-844. [CrossRef]

22. Kwon, S.H.; Pimentel, D.R.; Remondino, A.; Sawyer, D.B.; Colucci, W.S. $\mathrm{H}_{2} \mathrm{O}_{2}$ regulates cardiac myocyte phenotype via concentration-dependent activation of distinct kinase pathways. J. Mol. Cell. Cardiol. 2003, 35, 615-621. [CrossRef]

23. Carrizzo, A.; Izzo, C.; Forte, M.; Sommella, E.; Di Pietro, P.; Venturini, E.; Ciccarelli, M.; Galasso, G.; Rubattu, S.; Campiglia, P.; et al. A novel promising frontier for human health: The beneficial effects of nutraceuticals in cardiovascular diseases. Int. J. Mol. Sci. 2020, 21, 8706. [CrossRef]

24. Fukai, T.; Ushio-Fukai, M. Cross-talk between NADPH oxidase and mitochondria: Role in ROS signaling and angiogenesis. Cells 2020, 9, 1849. [CrossRef] [PubMed]

25. Lyall, R.; Nikoloski, Z.; Gechev, T. Comparative analysis of ROS network genes in extremophile eukaryotes. Int. J. Mol. Sci. 2020, 21, 9131. [CrossRef] [PubMed]

26. Pizzino, G.; Irrera, N.; Cucinotta, M.; Pallio, G.; Mannino, F.; Arcoraci, V.; Squadrito, F.; Altavilla, D.; Bitto, A. Oxidative stress: Harms and benefits for human health. Oxid. Med. Cell. Longev. 2017, 2017, 8416763. [CrossRef] [PubMed]

27. Belloc, F.; Dumain, P.; Boisseau, M.R.; Jalloustre, C.; Reiffers, J.; Bernard, P.; Lacombe, F. A flow cytometric method using Hoechst 33342 and propidium iodide for simultaneous cell cycle analysis and apoptosis determination in unfixed cells. Cytometry 1994, 17, 59-65. [CrossRef]

28. Cheng, F.; Yang, Y.; Zhang, L.; Cao, Y.; Yao, W.; Tang, Y.; Ding, A. A natural triterpene derivative from Euphorbia kansui inhibits cell proliferation and induces apoptosis against rat intestinal epithelioid cell line in vitro. Int. J. Mol. Sci. 2015, 16, 18956-18975. [CrossRef]

29. Thornberry, N.A.; Lazebnik, Y. Caspases: Enemies within. Science 1998, 281, 1312-1316. [CrossRef] [PubMed]

30. Perlman, H.; Zhang, X.; Chen, M.W.; Walsh, K.; Buttyan, R. An elevated bax/bcl-2 ratio corresponds with the onset of prostate epithelial cell apoptosis. Cell Death Differ. 1999, 6, 48-54. [CrossRef]

31. Peritore, A.F.; Siracusa, R.; Fusco, R.; Gugliandolo, E.; D’Amico, R.; Cordaro, M.; Crupi, R.; Genovese, T.; Impellizzeri, D.; Cuzzocrea, S.; et al. Ultramicronized Palmitoylethanolamide and Paracetamol, a New Association to Relieve Hyperalgesia and Pain in a Sciatic Nerve Injury Model in Rat. Int. J. Mol. Sci. 2020, 21, 3509. [CrossRef] 
32. Liu, T.; Zhang, L.; Joo, D.; Sun, S.C. NF-кB signaling in inflammation. Signal Transduct. Target. Ther. 2017,2 , 17023. [CrossRef] [PubMed]

33. Luo, J.L.; Kamata, H.; Karin, M. IKK/NF-kappaB signaling: Balancing life and death-A new approach to cancer therapy. J. Clin. Investig. 2005, 115, 2625-2632. [CrossRef]

34. Voll, R.E.; Herrmann, M.; Roth, E.A.; Stach, C.; Kalden, J.R.; Girkontaite, I. Immunosuppressive effects of apoptotic cells. Nature 1997, 390, 350-351. [CrossRef] [PubMed]

35. Luo, C.; Yang, H.; Tang, C.; Yao, G.; Kong, L.; He, H.; Zhou, Y. Kaempferol alleviates insulin resistance via hepatic IKK/NF-кB signal in type 2 diabetic rats. Int. Immunopharmacol. 2015, 28, 744-750. [CrossRef] [PubMed]

36. Gu, B.H.; Minh, N.V.; Lee, S.H.; Lim, S.W.; Lee, Y.M.; Lee, K.S.; Kim, D.K. Deoxyschisandrin inhibits $\mathrm{H}_{2} \mathrm{O}_{2}$-induced apoptotic cell death in intestinal epithelial cells through nuclear factor-kappaB. Int. J. Mol. Med. 2010, 26, 401-406.

37. DelloStritto, D.J.; Connell, P.J.; Dick, G.M.; Fancher, I.S.; Klarich, B.; Fahmy, J.N.; Kang, P.T.; Chen, Y.R.; Damron, D.S.; Thodeti, C.K.; et al. Differential regulation of TRPV1 channels by $\mathrm{H}_{2} \mathrm{O}_{2}$ : Implications for diabetic microvascular dysfunction. Basic Res. Cardiol. 2016, 111, 21. [CrossRef]

38. Saleh Al-Shehabi, T.; Iratni, R.; Eid, A.H. Anti-atherosclerotic plants which modulate the phenotype of vascular smooth muscle cells. Phytomedicine 2016, 23, 1068-1081. [CrossRef] [PubMed]

39. Fardoun, M.; Al-Shehabi, T.; El-Yazbi, A.; Issa, K.; Zouein, F.; Maaliki, D.; Iratni, R.; Eid, A.H. Ziziphus nummularia inhibits inflammation-induced atherogenic phenotype of human aortic smooth muscle cells. Oxid. Med. Cell. Longev. 2017, $2017,4134093$. [CrossRef] [PubMed]

40. Kirichenko, T.V.; Sukhorukov, V.N.; Markin, A.M.; Nikiforov, N.G.; Liu, P.Y.; Sobenin, I.A.; Tarasov, V.V.; Orekhov, A.N.; Aliev, G. Medicinal plants as a potential and successful treatment option in the context of atherosclerosis. Front. Pharmacol. 2020, 11, 403. [CrossRef]

41. Takanche, J.S.; Kim, J.E.; Han, S.H.; Yi, H.K. Effect of gomisin A on osteoblast differentiation in high glucose-mediated oxidative stress. Phytomedicine 2020, 66, 153107. [CrossRef] [PubMed]

42. Talebi, S.; Bagherniya, M.; Atkin, S.L.; Askari, G.; Orafai, H.M.; Sahebkar, A. The beneficial effects of nutraceuticals and natural products on small dense ldl levels, ldl particle number and ldl particle size: A clinical review. Lipids Health Dis. 2020, 19, 66. [CrossRef] [PubMed]

43. Shaito, A.; Thuan, D.T.B.; Phu, H.T.; Nguyen, T.H.D.; Hasan, H.; Halabi, S.; Abdelhady, S.; Nasrallah, G.K.; Eid, A.H.; Pintus, G. Herbal medicine for cardiovascular diseases: Efficacy, mechanisms, and safety. Front. Pharmacol. $2020,11,422$. [CrossRef] [PubMed]

44. Shen, M.Y.; Hsu, J.F.; Chen, F.Y.; Lu, J.; Chang, C.M.; Madjid, M.; Dean, J.; Dixon, R.A.F.; Shayani, S.; Chou, T.C.; et al. Combined LDL and VLDL electronegativity correlates with coronary heart disease risk in asymptomatic individuals. J. Clin. Med. 2019, 8, 1193. [CrossRef] [PubMed] 